\title{
A Abordagem Institucional na Contabilidade Gerencial
}

Pesquisas empíricas constatam que existe, atualmente, um aparente paradoxo no que diz respeito à prática da Contabilidade Gerencial. Apesar de fatores indutores e facilitadores do ambiente externo e do rol de novas técnicas e procedimentos à disposição dos gestores empresariais, o que se observa, efetivamente, na prática, é o baixo grau de implementação de novas técnicas e procedimentos de Contabilidade Gerencial nas empresas.

O tema da estabilidade e da mudança nos sistemas de Contabilidade Gerencial tem sido pouco explorado em pesquisas no Brasil; por outro lado, constitui tema relevante de pesquisa acadêmica no exterior, principalmente na Europa. A importância desse tema de pesquisa é de tal ordem que a revista acadêmica Management Accounting Research dedicou a edição completa do seu volume 12, em 2001, à publicação de artigos versando sobre essa temática.

O conhecimento teórico, no âmbito da Contabilidade Gerencial, é fortemente orientado pela teoria neoclássica da firma, mas muitos estudiosos observam que essa teoria não constitui referencial teórico único, adequado para explicar o desenvolvimento de sistemas de Contabilidade Gerencial. A teoria neoclássica foi desenvolvida por economistas para ajudá-los a prever comportamentos, efetuar estudos e análises em nível da indústria e do mercado como um todo. Não havia intenção de explicar o comportamento de gestores dentro das firmas. O pressuposto da racionalidade econômica dos indivíduos - que permeia a abordagem neoclássica - considera que os indivíduos estarão sempre tomando, individualmente, decisões racionais. Nesse sentido, todas as demais dimensões que cercam o ser humano, principalmente a psicológica e a sociológica, são desconsideradas na análise econômica do modelo neoclássico.

O interesse pela teoria institucional nas Ciências Sociais tem aumentado e três enfoques dessa teoria podem ser observados na literatura contábil: (i) nova sociologia institucional (NIS - New Institutional Sociology), (ii) nova economia institucional (NIE - New Institutional Economics) e (iii) velha economia institucional (OIE - Old Institutional Economics). Embora essas teorias tenham diferentes origens e raízes filosóficas diversas, elas compartilham um interesse comum pelos temas instituição e mudança institucional. O tema geral da perspectiva da denominada nova sociologia institucional (NIS) considera que, para assegurar a sua sobrevivência, a organização precisa se conformar às normas sociais de comportamento aceitável, além de atingir níveis de eficiência produtiva. A NIE abandona o pressuposto neoclássico da maximização da utilidade pelos indivíduos, porém não rompe completamente com a teoria econômica neoclássica. Nesse sentido, alguns autores mencionam que a nova economia institucional explica instituições capitalistas através de ferramental neoclássico. Os instrumentos dessa abordagem teórica são os arranjos institucionais de contratos e organizações em ambiente competitivo, em que a administração de firmas é disciplinada pela pressão competitiva dos mercados (de bens, de mão-de-obra, etc.). Considerando a teoria institucional segundo a ótica OIE, a instituição é o principal objeto de análise. A instituição é concebida como uma forma de pensar ou agir de algo que prevalece e permanece, o qual está inserido nos hábitos de um grupo ou nos costumes de um povo. Essa definição traz à tona o caráter social e cultural e enfatiza a importância do comportamento habitual.

O enfoque institucional fornece uma perspectiva alternativa para o estudo das práticas da Contabilidade Gerencial. Essa perspectiva induz o pesquisador a uma análise detida da natureza das práticas vigentes na empresa. Muito mais do que desqualificar determinadas práticas da Contabilidade Gerencial que não se conformam com as diretrizes das modernas teorias apresentadas nos livros-texto, a Contabilidade Gerencial deve ser estudada como um produto de processos institucionais que dão coerência e significado para o comportamento da organização. Na prática, os sistemas de Contabilidade Gerencial não incorporam, necessariamente, os melhores conceitos técnicos ditados pela teoria convencional, mas sim os conceitos que estejam em linha com as expectativas dos indivíduos e em conformidade com as normas sociais de comportamento aceitável na empresa e que se convertam em hábitos e rotinas amplamente aceitos pelos indivíduos da organização. Em nossa opinião, os sistemas de Contabilidade Gerencial deveriam ser planejados à luz da abordagem neoclássica e implementados considerando, sobretudo, as premissas da abordagem institucional.

Reinaldo Guerreiro

Professor Titular do Departamento de Contabilidade e Atuária da FEA/USP 